\title{
CONJOINED TWINS
}

\author{
Col MK BEHERA* , Maj S JAIN ${ }^{+}$
}

MJAFI 2002; 58 : 163-164

KEY WORDS :Conjoined twins; Monozygous

\section{Introduction}

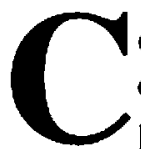

onjoined twins is a rare entity and since ancient times it has fascinated both the general population and medical fraternity alike. This is associated with high mortality and separation has long been a surgical challenge. This is seen in 1 in 80,000 to 100,000 deliveries. Females predominate over males and approximately $40-60 \%$ are still born and $35 \%$ survive only one day. We report a case of conjoined twins because of rarity.

\section{Case Report}

A 25 year old unbooked mother was admitted with labour pain to a peripheral service hospital at 36 weeks of gestation with pregnancy induced hyperension and impending eclampsia. A female conjoined twin weighing $3.8 \mathrm{Kg}$ was delivered after emergency caesarean section. Placenta was monochorionic and monoamniotic. Both the babies had mild asphyxia at birth and were resuscitated. One of the twins appeared bigger than the other. Both were fused anteriorly at chest and upper abdominal wall but upper part of the sternum and neck and lower part of abdomen were not fused (Fig-1). Heart sounds were audible over the fused sternum and air entry to both lungs was good. Externally it appeared to have single heart and liver.

Blood haemogram, PCV, blood sugar and peripheral smear study were within normal limit. On ultrasonographic examination brain appeared normal, there was a single heart at midline with well appreciated chambers, a single liver at fusion site. kidneys were visualized and in the smaller baby the kyphosis of spine was detected at mid thoracic and lumbar region.

Both the babies passed urine and meconium and vital parameters remained stable. This conjoined twin was managed with vita$\min \mathrm{K}$, intravenous fluid, antibiotics and other supportive and symptomatic therapy without any surgical intervention. One of the twins developed bronchopneumonia with respiratory distress. tachypnea and retractions on $3^{\text {rd }}$ day and inspite of antibiotics. oxygen and other supportive measures baby succumbed on $4^{\text {th }}$ day and the other baby died immediately thereafter.

\section{Discussion}

Conjoined twins are popularly known as Siamese twins after the birth of famous conjoined twins Chang and Eng Bunker in 1811 in Siam (now Thailand). They lived unseparated for 63 years and at the age of 31 years married two sisters who bore 21 children.
Chang died of bronchitis and Eng soon after of fright [1].

Conjoined iwins are monozygous and therefore have same sex. Majority of cases have a monochorionic and monoamniotic placenta. 2 cases of monocho-rionic, diamniotic conjoined twins have been reported in literature [2]. There are two theories explaining the etiology of conjoined twins. Collision theory [3] is that, in which two previously duplicate embryonic axes fuse before tissue differentiation and fission theory is the one, in which the embryonic tissue divides incompletely, remaining fused at some points (or) point. The latter theory is more acceptable. At about $2^{\text {nd }}$ week of normal twining process, the inner cell mass splits into two separate and equal halves each usually producing a single individual. Conjoined

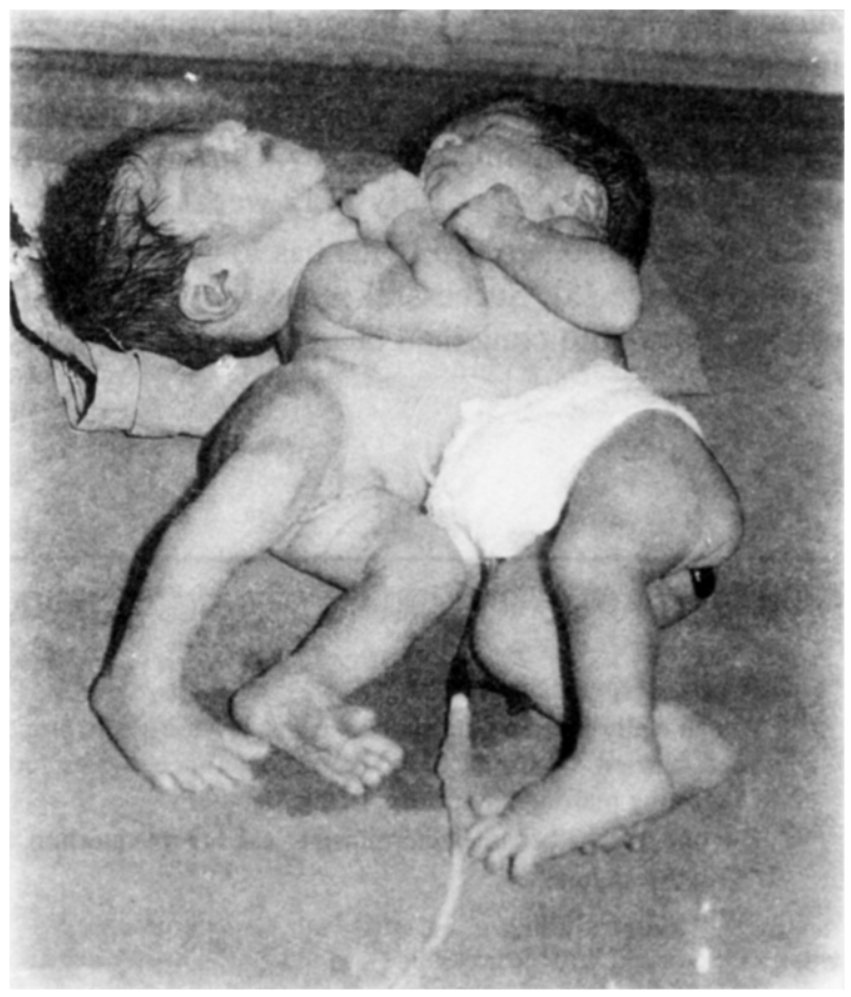

Fig. 1: Conjoined twins

\footnotetext{
"Senior Advisor (Paediatrics), Command Hospital, (Central Command), Lucknow-226 002, ${ }^{+}$Graded Specialist (Paediatrics), Military Hospital, Babina- 284401.
} 
twins result from an arrest in division of the inner cell mass [4].

Conjoined twins are classified depending on the site of conjunction. (A) Thoracopagous - $(40 \%)$, most common and fusion is at the level of the chest with common sternum, thoracic cage, diaphragm and abdominal walls down to umbilicus. In this variety $75 \%$ have conjoined heart, $50 \%$ have fusion of intestinal tracts and virtually all have a shared liver. (B) Omphalopagous or Xiphipagous - $(34 \%)$, they are usually joined anteriorly from the xiphoid to the umbilicus. (C) Pyopagous - $(18 \%)$, they are joined at gluteal region with fusion of sacrum. They usually have a common sacral spinal canal and single anus and rectum. (D) Ischiopagous - $(6 \%)$, there is a junction at the pelvic level with sharing of genitourinary structure, rectum and liver. (E) Craniopagous - (1-2\%), the fusion is at the skull involving the brow, vertex, or parietal bones. Craniothoracopagous, a rare variety with a single fused head and two faces looking in opposite directions is referred to as Janiceps twins. (F) Heteropagous - these are asymmetric forms. There may be parasitic attachment in nonduplicated fashion of any portion of the body or even within the body as a fetus in feto. Apart from junction at one anatomical site, conjoined twins can result from joining of multiple sites, craniothoracopagus, xiphoomphaloischio-pagus. Prenatal diagnosis of conjoined twins is essential for appropriate obstetric management and allows parents the option of intercepting pregnancy. Ultrasonographically it can be detected as early as 12 weeks of age.

Separation of conjoined twins has long been a surgical challenge [5]. Successful separation of thoracopagous twins with conjoined heart is difficult and the results are very poor. Without cardiac junction, separation is feasible. Most successful cases are reported in omphalopagus twins. The outlook for craniopagus form relates to whether the brain junction is complete or incomplete but usually the result is poor. In ischiopagous twinning there will be complicated form of conjunction at lower gastro intestinal tract as well as pelvic skeletal structures and although separation has been reported, children are left with severe handicaps. Fortunately, in pyopagous twins the structures that require separation are not generally essential for survival.

Siamese twins in majority of cases are stillborn or die soon after birth. Attempt at surgery depends on the type of conjoined twins, the degree and type of organs shared by the twins, associated malformations, general condition of the twins and above all on the medical and surgical setup available in the center.

\section{References}

1. Kulkarni ML, Suresh Kumar C. George VG, Venkataramana V. Conjoined twins. Ind Pediatr 1994;31:1017-24.

2. Weston PJ, Ives EJ, Honors RLH, Lees GM, Sinclair BD, Schiff D. Monochorionic diamniotic minimally conjoined twins - A case report. Am J Med Genet 1990;37:558-661.

3. Wedberg R, Kalpan C, Leopold G, Porreco R, Resnik R, Benirschke K. Cephalothoracopagus twinning. Obstet Gynecol 1979; 54 : 392-6.

4. Revenis ME, Johnson LA. Multiple gestation In : Avery GB, Fletcher MA, Mhairi G, editors. Neonatology : Pathophysiology and Management of Newbom. $4^{\text {th }}$ ed. Philadelphia : JB Lippincott Company. 1994;417-25.

5. Singh Meharban. Conjoined twins. In : Singh Meharban, editor. Care of New Bom, $5^{\text {th }}$ ed. New Delhi : Sagar publications. 1999;444-5. 